\title{
Risk factors for the presence of Fasciola hepatica antibodies in bulk-milk samples and their association with milk production decreases, in Cuban dairy cattle
}

Amilcar Arenal ${ }^{1 *}{ }^{*}$ D, Yipsi García ${ }^{1 \dagger}$, Lídice Quesada $^{1}$, Dayamis Velázquez , Diamela Sánchez ${ }^{1}$, Mayelin Peña ${ }^{1}$, Asnaldo Suárez ${ }^{1}$, Arnielis Díaz ${ }^{1}$, Yuliet Sánchez ${ }^{1}$, Stijn Casaert², Jan van Dijk³ ${ }^{3}$ Jozef Vercruysse ${ }^{2}$

and Johannes Charlier ${ }^{4}$

\begin{abstract}
Background: Worldwide, Fasciola hepatica infection causes high production losses in the livestock industry. Recently, studies have analyzed the association between measurements of $F$. hepatica infection intensity and herd management practices. The aim of the present study, the first of its kind in a subtropical region, was to evaluate associations between $F$. hepatica bulk-tank milk ELISA results with herd management factors and milk yield in dairy herds, in Camagüey, Cuba. The SVANOVIR ${ }^{\circledast}$. hepatica-AB ELISA was used to measure $F$. hepatica antibody levels in a random sample of 516 dairy herds during the period of May-July of 2014. Farm management practice data were collected using a questionnaire.

Results: With $82 \%$ of the herds testing positive, the results indicate that $F$. hepatica is very widespread in this area. Reductions in milk production of 18 and 32\% were observed in herds with Optical Density Ratios (ODR) of 0.3-0.6 and $>0.6$, respectively, when compared to herds with $\mathrm{ODR}<0.3$. Overall, the longer the milking cows were put out to pasture, the higher the levels of anti-parasite antibodies. Co-grazing with sheep and goats also significantly increased the risk of high ODR.

Conclusions: Our data show a widespread occurrence of the parasite as well as a major potential impact of the infection on the Cuban development goal of becoming self-sufficient in milk production. Our risk factor analysis suggests that the prevention of infection around water sources, and the separation of cattle from small ruminants could be useful control measures. This is the first epidemiological survey of $F$. hepatica abundance, and associated reductions in milk yield, in dairy herds in Cuba.
\end{abstract}

Keywords: Bulk-tank, Milk production, Risk factors, Liver fluke, Helminth, Ruminants, ELISA

\section{Background}

During the 1980s, Cuban dairy cattle production levels enjoyed the highest growth in Latin America. In 1989, production peaked at 1134 million liters of milk. Since then, the Cuban dairy industry has faced momentous changes and challenges. During the Cuban economic

\footnotetext{
* Correspondence: amilcar.arenal@reduc.edu.cu

${ }^{\dagger}$ Amilcar Arenal and Yipsi García contributed equally to this work.

'Department of Morpho-Physiology, University of Camagüey Ignacio

Agramonte Loynaz, Km 5 1⁄2, 74650 Camagüey, Cuba

Full list of author information is available at the end of the article
}

crisis of the Nineties, milk production dropped back and was recorded at 353 million liters in 2005 [1]. At the same time, pure-bred Holstein herds, which had made up $72 \%$ of all herds, were reduced to $12 \%$, with crossbreeding of Holstein dairy cows and Zebu cattle becoming the norm [2]. The percentage of dairy cows kept on privately-owned, as opposed to state-owned, farms increased from 20 to $80 \%$. In recent years, milk production rebounded to approximately 600 million liters. However, this is estimated to be only $50 \%$ of the current Cuban milk demand [2]. To raise self-sufficiency levels in

(C) The Author(s). 2018 Open Access This article is distributed under the terms of the Creative Commons Attribution 4.0 International License (http://creativecommons.org/licenses/by/4.0/), which permits unrestricted use, distribution, and 
subtropical countries like Cuba, it is clearly important to evaluate existing milk production limitations.

In Cuba, milk production is based on the utilization of pastures in the rainy season and green and preserved forages, supplemented by sugar-industry by-products, in the dry season. The most important limitation on milk production in Cuba is thought to be that these nutritional resources contain less than desirable energy density [3]. This lack manifests itself especially in the dry season, by halving of milk production. Another likely factor reducing yield milk is infections, especially with helminths. However, the prevalence of economically important helminths on dairy farms, and their impact on milk production, has not been quantified in Cuba. Existing impact studies were all carried out in different climatic zones, and for very different farming systems $[4,5]$, and therefore it is unlikely that the results of such studies can be applied to milk production systems in subtropical regions.

Helminth infections are recognized as a major limitation for livestock production throughout the tropics and elsewhere [6]. Among these, infections with Fasciola hepatica are responsible for significant economic losses in the cattle industry, due to mortality, reduced production of meat and milk and costs of deworming.

Various diagnostic methods based on detecting antibodies specific for $F$. hepatica in feces, serum, meat juice and milk have been described previously [7-9]. The wide availability and simplicity of these tests have facilitated large epidemiological studies [10] and evaluation of the association between fluke infection status and milk production parameters [11]. The magnitude of such effects has been shown to depend on the production system $[4,12,13]$, lending argument to the need to study such losses in disparate epidemiological and production settings.

To date, the only epidemiological data available in Cuba are prevalence data from routine inspections in slaughterhouses in the central provinces showing prevalences of $20-50 \%$ for $F$. hepatica [14, 15]. To define the potential constraint of helminth infections on dairy productivity and initiate the development of $F$. hepatica herd management recommendations, we conducted a targeted survey in the major milk producing province of Camagüey and deployed a bulk-tank milk (BTM) ELISA test as a tool for diagnosis of fasciolosis in Cuban dairy cattle.

\section{Results}

\section{Fasciola hepatica antibodies}

The mean, SD and range of the F. hepatica ODR were $0.510,0.201$ and 0.049 to 1.192 , respectively. According to the manufacturer's interpretation criteria $82.2 \%$ of the herds tested positive for $F$. hepatica (>0.3 ODR, 95\% confidence interval: $0.561-0.591$ ), while $35.7 \%$ of herds were likely to suffer significant production decreases (> 0.6 ODR, 95\% confidence interval: 0.705-0.736).

\section{Associations of Fasciola hepatica antibodies and management factors with milk yield}

Complete data (consisting of BTM ELISA results combined with complete questionnaire and milk production information) was obtained from 516 out of the 650 selected farms. The observed average milk yield per dairy cow per year was $1024 \mathrm{~kg}$ (95\% confidence interval: 996-1051 kg). The average milk yield per dairy cow per year of the negative herds $(<0.3$ ODR) was $1266 \mathrm{~kg}(95 \%$ confidence interval: $1200-1333 \mathrm{~kg}$ ). There was a significant negative correlation between ODR and milk yield $(R=-0.44 ; P<0.01)$. In the one-way ANOVA, the differences in average milk yield per cow per year between F. hepatica $>0.6$ ODR and 0.3-0.6 ODR comparing to negative herds $(<0.3$ ODR) were $401 \mathrm{~kg}(32 \%)$ and $226 \mathrm{~kg}(18 \%)$, respectively (Fig. 1).

The management factors that were significantly associated through univariable regression with milk yield are listed in Table 1. Grass proportion in the dry season (higher milk yield with higher grass proportion), watering place (lower milk yield for pool/pond/brook vs. well), farm total area (lower milk yield in smaller farms), municipality, nutritional supplement in dry (lower milk yield in case of supplement) and rainy season (higher milk yield in case of supplement), and ODR (lower milk yield with higher ODR) were all associated with milk yield. The multivariable regression model to investigate the association between ODR and milk yield (Table 2) retained ODR and municipality as the two significant predictors. According to this model, an increase in $F$. hepatica ODR over the interquartile range (0.33-0.64) is associated with a reduction in average milk yield of $183 \mathrm{~kg} /$ cow per year (14\%).

\section{Associations of Fasciola hepatica antibodies with management factors}

The frequencies at which different categories of management variables were measured, and their corresponding ODR are listed in Table 3. The UEB farms (state sector) presented significantly higher ODR values compared to the private sector (CPA and CCS) and also UBPC (state sector). Farms with more than 30 ha had a significantly higher ODR compared to the smaller ones. When the cows were grazed with sheep and goats the ODR was significantly higher compared to the farms where cows are grazed without other species or only with horses. Herds with access to pool/pond/brookhad significantly higher ODR compared to herds with wells as water source. It was also observed that farms with a lower grass proportion in the cow's diet in the dry season presented a significantly higher ODR. In the dry season, a lower ODR value was also found when the grazing time was less than $6 \mathrm{~h}$. The multivariate regression model identified grass proportion 
a

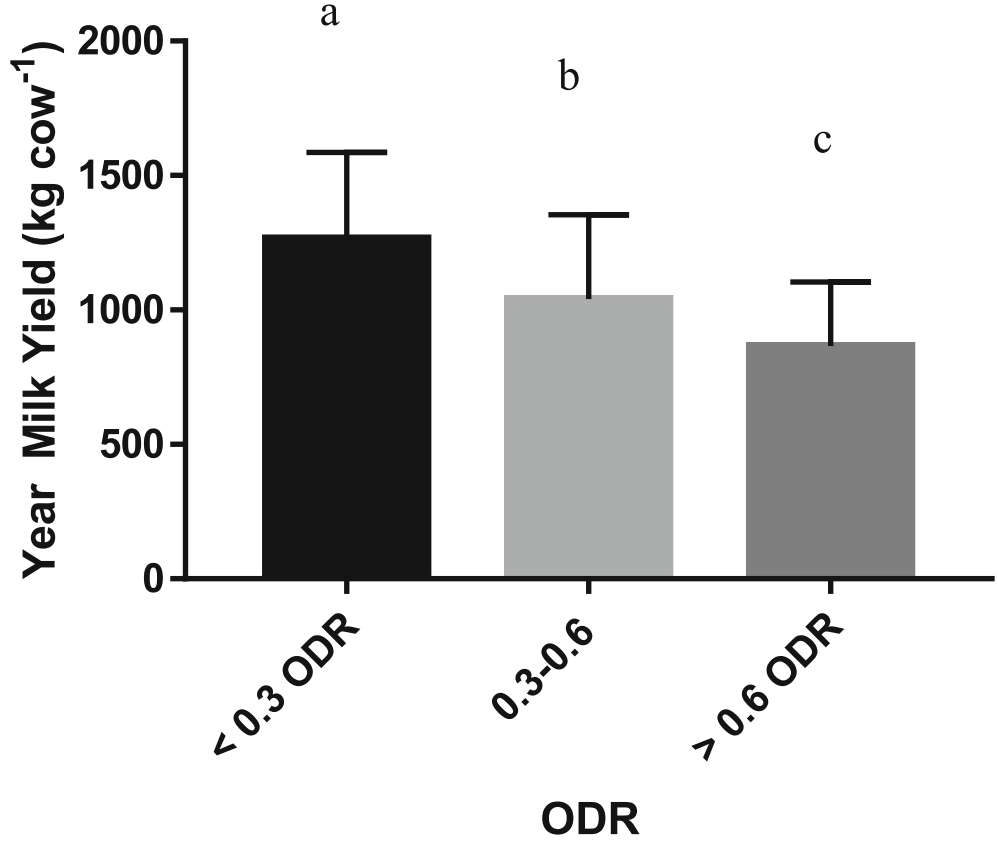

Fig. 1 Milk production per cow per year according to the ELISA cut-off of the relative optical density ratio (ODR). Data are presented as mean $\pm S E(<$ $0.300, N=92 ; 0.300-0.600, N=257 ;>0.600, N=167)$. Bar indicates the SE. Different letters indicate significant differences among groups $(P<0.001)$

in the dry season and municipality as the two most significant associated factors with $F$. hepatica ODR (Table 4).

\section{Discussion}

Our study found evidence of $F$. hepatica infection on 4 out of 5 farms in the major milk producing province in Cuba. Moreover, this infection was not only highly prevalent, but also significantly associated with decreases in milk yield.
In previous abattoir-based studies in Cuba, F. hepatica parasites were observed to be present between 20 and $50 \%$ of the animals. However, the latter studies were conducted at the individual cow level $[14,15]$ and in a different geographical region of Cuba. Moreover, it is known that meat inspection at the slaughterhouse has a lower sensitivity than serology-based methods [16].

The evidence of widespread $F$. hepatica infection in Cuban dairy herds, together with the known deleterious

Table 1 Variables significantly $(P<0.05)$ associated through univariable regression with annual milk yield (kg/cow/year) in Camagüey province, Cuba

\begin{tabular}{|c|c|c|c|c|c|}
\hline Variable & Parameter & $B$ & Std. Error & $R^{2}$ & Sig. \\
\hline \multirow[t]{2}{*}{$\overline{O D R}$} & Intercept & 1387.5 & 34.8 & 0.197 & \\
\hline & ODR & -712.3 & 63.5 & & $<0.001$ \\
\hline \multirow[t]{2}{*}{ Municipality ${ }^{a}$} & Intercept & 978.1 & 34.9 & 0.153 & \\
\hline & Municipality & & & & $<0.001$ \\
\hline \multirow[t]{2}{*}{ Grass proportion ${ }^{a}$} & Intercept & 940.7 & 25.8 & 0.051 & \\
\hline & Grass proportion & & & & $<0.001$ \\
\hline \multirow[t]{2}{*}{ Watering place ${ }^{a}$} & Intercept & 1044.0 & 15.9 & 0.015 & \\
\hline & Watering place & & & & 0.006 \\
\hline \multirow[t]{2}{*}{ Farm total area ${ }^{a}$} & Intercept & 1050.6 & 24.7 & 0.012 & \\
\hline & Farm total area & & & & 0.048 \\
\hline \multirow[t]{2}{*}{ Nutritional supplement in dry season ${ }^{a}$} & Intercept & 1054.7 & 16.8 & 0.022 & \\
\hline & Nutritional supplement dry season & & & & 0.001 \\
\hline \multirow[t]{2}{*}{ Nutritional supplement in rainy season ${ }^{a}$} & Intercept & 945.3 & 21.9 & 0.040 & \\
\hline & Nutritional supplement in rainy season & & & & $<0.001$ \\
\hline
\end{tabular}


Table 2 Association between $F$. hepatica antibody level and milk yield (kg/cow per year) in Camagüey province, Cuba ${ }^{a}$

\begin{tabular}{llll}
\hline Parameter & B & Std. Error & Sig. \\
\hline Intercept & 1300.3 & 49.4 & $<0.001$ \\
ODR & -590.9 & 68.1 & $<0.001$ \\
Municipality & & & $<0.001$ \\
$\quad$ Camagüey & -107.0 & 50.3 & 0.034 \\
Céspedes & -138.1 & 81.9 & 0.093 \\
Esmeralda & -102.2 & 72.2 & 0.157 \\
Florida & -100.2 & 66.9 & 0.135 \\
Guaimaro & 129.7 & 46.5 & 0.005 \\
Jimaguayú & 16.8 & 50.5 & 0.739 \\
Minas & -35.1 & 66.9 & 0.600 \\
Najasa & 86.5 & 54.5 & 0.113 \\
Nuevitas & 13.3 & 67.0 & 0.842 \\
S.Cubitas & 64.9 & 62.7 & 0.302 \\
Santa Cruz del Sur & 144.8 & 54.6 & 0.008 \\
Sibanicú & 70.2 & 55.8 & 0.210 \\
Vertientes & Base &. &. \\
\hline
\end{tabular}

${ }^{\mathrm{a}}$ Multivariable linear regression model $\left(R^{2}=0.264, N=516\right.$ dairy herds $)$

effects of $F$. hepatica on animal welfare and productivity suggest than these infections should be considered of major importance in Cuban dairy farms. However, on high-input, intensive, Holstein-pedigree farms, milk production per cow per year was more than 6 times that of the Cuban mixed breed cattle studied here. Cuban cattle are not genetically capable of achieving such high levels of milk production, they eat a less nutritious diet and, in subtropical climates, they often face higher parasite burdens. Because Cuban cattle are likely under lower metabolic stress than their European counterparts in intensive production systems, it could be proposed that parasite-ascribed decreases in milk production in Cuba should be lower than, for example, in Europe. However, in the UK, in high yielding herds, $F$. hepatica - associated decreases were estimated at $15 \%$ [4], compared to estimated decreases of $18 \%$ to $32 \%$ in the present study. The Cuban estimate is substantially higher than the $3 \%$ reduction described in Belgium in herds with high ODR [11] and the 6\% in Spanish herds with high infection levels [13]. Partly, these differences may be ascribed to the fact that we did not control for some confounding factors, such as lactation stage, age composition or somatic cell count data in our analysis. This was not possible, as these data are not routinely collected in Cuban dairy farms. Therefore, further elucidation of the true and recoverable production impact would require an intervention trial using anthelmintic treatment under field conditions [17].
The impact of parasite infections on food security may be more keenly felt in countries where demand is already outstripping supply. At the same time, options for control are likely to be more limited in subtropical systems. For example, with very few water sources available, options for pasture rotation are limited. In Cuba, anthelmintic treatments for $F$. hepatica are not used routinely either because of a lack of availability in the Cuban market and/or a lack of diagnostic routine. This study made a start with the identification of risk factors, which should aid in the development of control recommendations for the Cuban dairy sector. Different farming systems had different ODR levels. UEB farms, which are normally the larger farms, with more extensive access to suitable habitats for lymnaeid snails, had higher ODRs. Similarly, farms with a higher number of hectares available had higher ODRs. In Denmark, larger dairy herds were also more prone to $F$. hepatica infection [18]. In Turkey and Tanzania, large-scale and traditional (stationary herds without effective disease control) dairy farms presented higher prevalence of Fasciola sp. than small-scale farms $[19,20]$. This may be related to intensively grazed pastures and to an increased likelihood of cattle encountering fluke-contaminated snail habitats on larger farms.

Access to suitable habitats for lymnaeid snails, usually man-made ponds of stagnant water used to water cattle, indeed appears to be an important factor contributing to higher levels of infection. In this study, farms with less grass as a proportion of the total diet, available during the dry season, had significantly higher antibody titers. On these farms, cattle will normally be congregated around these habitats for lymnaeid snails and receive supplementation with other food sources, such as sugar cane byproducts. They will therefore have increased contact time with metacercaria-contaminated snail-infested areas. Access to, and type of, water sources could be the key overriding factor in fluke transmission in Cuba. This may be an important area to focus on in terms of limiting losses to the parasite.

Grazing alongside horses was not a significant risk factor whereas, in agreement with other studies [21], co-grazing with small ruminants clearly increased the risk of higher ODR levels.

There were significant differences in ODR levels between municipalities. The reason for this could include local environmental differences as well as differences in local farm management practices [22]. In the UK, McCann, Baylis and Williams [23] detected rainfall as the main responsible factor of variation $(23 \%)$ in $F$. hepatica BTM antibody levels, whilst farm management explained about $21 \%$ of variation. Bennema et al. [24] found that in regions with relatively homogenous climatic and environmental conditions, management 
Table 3 Frequency and percentages of the herd characteristics of dairy herds sampled in Cuba $(N=516)$ in a cross-sectional questionnaire survey conducted in March-July, 2014

\begin{tabular}{|c|c|c|c|c|c|c|c|}
\hline \multicolumn{3}{|l|}{ Variable } & \multirow{2}{*}{$\frac{\%}{10.1}$} & \multirow{2}{*}{$\frac{N}{52}$} & \multirow{2}{*}{$\frac{\text { Mean ODR }}{0.600^{\mathrm{a}}}$} & \multirow{2}{*}{$\frac{S D}{0.188}$} & \multirow{2}{*}{$\frac{\text { Range }}{0.05-0.99}$} \\
\hline Type of production & State $^{a}$ & UEB & & & & & \\
\hline & & UBPC & 25.6 & 132 & $0.522^{\mathrm{b}}$ & 0.187 & $0.05-0.98$ \\
\hline & Private $^{a}$ & CPA & 15.1 & 78 & $0.496^{\mathrm{b}}$ & 0.177 & $0.07-0.89$ \\
\hline & & CCS & 49.2 & 254 & $0.490^{\mathrm{b}}$ & 0.212 & $0.05-1.19$ \\
\hline \multirow[t]{2}{*}{ Type of Herd } & Dairy only & & 54.8 & 283 & $0.511^{\mathrm{a}}$ & 0.208 & $0.05-1.19$ \\
\hline & Both beef & & 45.2 & 233 & $0.509^{a}$ & 0.192 & $0.05-1.03$ \\
\hline \multirow[t]{3}{*}{ Farm total area } & $<=13.42 \mathrm{~h}$ & & 32.8 & 169 & $0.474^{\mathrm{b}}$ & 0.194 & $0.12-1.03$ \\
\hline & $>13.42$ an & ha & 14.0 & 72 & $0.472^{b}$ & 0.186 & $0.05-0.88$ \\
\hline & $>30$ ha & & 53.3 & 275 & $0.543^{\mathrm{a}}$ & 0.204 & $0.05-1.19$ \\
\hline \multirow[t]{3}{*}{ Herd size (adult cows: lactating + dry): } & $<30$ & & 55.4 & 286 & $0.499^{\mathrm{a}}$ & 0.217 & $0.05-1.03$ \\
\hline & $30-60$ & & 30.6 & 158 & $0.539^{a}$ & 0.200 & $0.05-1.19$ \\
\hline & $>60$ & & 14.0 & 72 & $0.534^{\mathrm{a}}$ & 0.215 & $0.07-0.89$ \\
\hline Deworming of cows & & & 3.1 & 16 & $0.539^{\mathrm{a}}$ & 0.187 & $0.28-0.98$ \\
\hline \multicolumn{8}{|l|}{ Not dewormed } \\
\hline \multicolumn{3}{|l|}{ Dewormed when worm problems } & 22.9 & 118 & $0.480^{\mathrm{a}}$ & 0.197 & $0.05-0.89$ \\
\hline \multicolumn{3}{|l|}{ Preventive treatment } & 74.0 & 382 & $0.518^{a}$ & 0.202 & $0.05-1.19$ \\
\hline \multicolumn{8}{|l|}{ Cows grazed together with other species } \\
\hline \multicolumn{3}{|l|}{ Sheep and goats } & 19.2 & 99 & $0.552^{\mathrm{a}}$ & 0.178 & $0.05-1.03$ \\
\hline \multicolumn{3}{|l|}{ Horse } & 21.5 & 111 & $0.501^{b}$ & 0.196 & $0.12-0.99$ \\
\hline \multicolumn{3}{|l|}{ None } & 59.3 & 306 & $0.500^{\mathrm{b}}$ & 0.208 & $0.05-1.19$ \\
\hline \multicolumn{8}{|c|}{ Stocking rate: average number of cows per hectare on a parcel? } \\
\hline \multicolumn{3}{|l|}{$<1$} & 40.3 & 208 & $0.496^{\mathrm{a}}$ & 0.185 & $0.07-1.19$ \\
\hline \multicolumn{3}{|l|}{$1-2$} & 56.2 & 290 & $0.521^{a}$ & 0.210 & $0.05-0.99$ \\
\hline \multicolumn{3}{|l|}{$>2$} & 3.5 & 18 & $0.501^{\mathrm{a}}$ & 0.232 & $0.05-0.85$ \\
\hline \multicolumn{8}{|l|}{ Watering place } \\
\hline \multicolumn{3}{|l|}{ Pool/pond/brook } & 20.9 & 108 & $0.561^{\mathrm{a}}$ & 0.206 & $0.07-1.19$ \\
\hline \multicolumn{3}{|l|}{ Pump on pasture } & 79.1 & 408 & $0.497^{\mathrm{b}}$ & 0.198 & $0.05-0.99$ \\
\hline \multicolumn{8}{|l|}{ Rotational grazing of cows } \\
\hline Yes & & & 5.4 & 28 & $0.511^{\mathrm{a}}$ & 0.190 & $0.15-0.82$ \\
\hline No & & & 94.6 & 488 & $0.502^{\mathrm{a}}$ & 0.201 & $0.05-1.19$ \\
\hline What was the cow's grazing time per $\mathrm{c}$ & ring the $d r y$ & & & & & & \\
\hline Day and night & & & 14.0 & 72 & $0.542^{a}$ & 0.165 & $0.05-0.76$ \\
\hline$<6 \mathrm{~h}$ per day & & & 62.6 & 322 & $0.498^{b}$ & 0.217 & $0.05-1.19$ \\
\hline$>6 \mathrm{~h}$ per day & & & 23.4 & 122 & $0.541^{\mathrm{a}}$ & 0.167 & $0.05-0.98$ \\
\hline What was the cow's grazing time per $\mathrm{c}$ & ring the rail & & & & & & \\
\hline Day and night & & & 11.0 & 57 & $0.513^{\mathrm{a}}$ & 0.168 & $0.05-0.80$ \\
\hline$<6$ h per day & & & 42.4 & 219 & $0.504^{\mathrm{a}}$ & 0.205 & $0.05-1.19$ \\
\hline$>6 \mathrm{~h}$ per day & & & 46.5 & 240 & $0.515^{\mathrm{a}}$ & 0.205 & $0.05-0.99$ \\
\hline Grass proportion dry season & & & & & & & \\
\hline $81-100$ & & & 20.5 & 106 & $0.406^{c}$ & 0.201 & $0.05-0.88$ \\
\hline $51-80$ & & & 50.6 & 261 & $0.511^{b}$ & 0.198 & $0.07-0.99$ \\
\hline$<=50$ & & & 28.9 & 149 & $0.583^{\mathrm{a}}$ & 0.172 & $0.05-1.19$ \\
\hline
\end{tabular}


Table 3 Frequency and percentages of the herd characteristics of dairy herds sampled in Cuba $(N=516)$ in a cross-sectional questionnaire survey conducted in March-July, 2014 (Continued)

\begin{tabular}{|c|c|c|c|c|c|c|}
\hline \multicolumn{2}{|l|}{ Variable } & $\%$ & $\mathrm{~N}$ & Mean ODR & SD & Range \\
\hline \multicolumn{7}{|c|}{ Grass proportion rainy season } \\
\hline \multicolumn{2}{|l|}{$81-100$} & 30.4 & 157 & $0.501^{\mathrm{a}}$ & 0.188 & $90.05-0.91$ \\
\hline \multicolumn{2}{|l|}{$51-80$} & 52.3 & 270 & $0.519^{\mathrm{a}}$ & 0.205 & $0.05-1.19$ \\
\hline \multicolumn{2}{|l|}{$<=50$} & 17.2 & 89 & $0.501^{\mathrm{a}}$ & 0.215 & $0.12-1.03$ \\
\hline \multicolumn{7}{|c|}{ Grass Mowing } \\
\hline \multicolumn{2}{|l|}{$51-100 \%$} & 27.9 & 144 & $0.496^{a}$ & 0.187 & $0.05-0.88$ \\
\hline \multicolumn{2}{|l|}{$<50 \%$} & 43.0 & 222 & $0.512^{a}$ & 0.210 & $0.05-1.03$ \\
\hline \multicolumn{2}{|l|}{ Never } & 29.1 & 150 & $0.522^{\mathrm{a}}$ & 0.200 & $0.07-1.19$ \\
\hline \multirow[t]{13}{*}{ Municipality } & Camagüey & $10.7 \%$ & 55 & $0.630^{\mathrm{a}}$ & 0.114 & $0.37-.87$ \\
\hline & Céspedes & $2.7 \%$ & 14 & $0.634^{\mathrm{a}}$ & 0.303 & $0.05-1.19$ \\
\hline & Esmeralda & $3.7 \%$ & 19 & $0.493^{a, b, c}$ & 0.196 & $.15-.82$ \\
\hline & Florida & $4.5 \%$ & 23 & $0.548^{a, b}$ & 0.171 & $0.25-.86$ \\
\hline & Guaimaro & $15.7 \%$ & 81 & $0.381^{c, d}$ & 0.179 & $0.05-.88$ \\
\hline & Jimaguayú & $10.3 \%$ & 53 & $0.567^{\mathrm{a}, \mathrm{b}}$ & 0.179 & $0.07-.99$ \\
\hline & Minas & $4.5 \%$ & 23 & $0.511^{a, b}$ & 0.254 & $0.09-.88$ \\
\hline & Najasa & $8.1 \%$ & 42 & $0.455^{b, c, d}$ & 0.142 & $0.17-.77$ \\
\hline & Nuevitas & $4.5 \%$ & 23 & $0.598^{\mathrm{a}, \mathrm{b}}$ & 0.263 & $0.07-.99$ \\
\hline & S.Cubitas & $5.6 \%$ & 29 & $0.360^{d}$ & 0.192 & $0.11-.91$ \\
\hline & Santa Cruz del Sur & $7.9 \%$ & 41 & $0.572^{a, b}$ & 0.177 & $0.15-.91$ \\
\hline & Sibanicú & $7.6 \%$ & 39 & $0.464^{b, c, d}$ & 0.171 & 0.17 .84 \\
\hline & Vertientes & $14.3 \%$ & 74 & $0.545^{a, b}$ & 0.179 & 0.05 .88 \\
\hline
\end{tabular}

Different letters indicate significant differences between groups $(P<0.05)$

aEB (Basic unit from the state), UBPC (Cooperative Unit Basic of Production), CCS (Credit and Service Cooperative) and CPA (Agropecuary

Production Cooperative)

factors are the primary factors determining $F$. hepatica infection risk. Further research is recommended to determine the importance of water source as well as of infection and the local environmental (soil type, local pasture, infection with other parasite, bacterial interactions, landscape features) and climatic conditions affecting the infection risk. Moreover, it is necessary to evaluate the impact of host factors such as age and genetic make-up. Ultimately, this could result in local risk maps and evidence-based and practical management recommendations such as sanitation of pastures and water sources and targeted anthelmintic treatment during periods of highest infection pressure [24, 25].

\section{Conclusions}

We have provided baseline $F$. hepatica exposure data for the major milk production area of Cuba. Our data show a widespread occurrence of the parasite, as well as a major potential impact of this infection on the Cuban development goal to become self-sufficient in milk production. Our risk factor analysis suggests that the prevention of infection around habitats suitable for lymnaeid snails, and that the separation of cattle and small ruminants could be useful control recommendations. However, further research to confirm the importance of these risk factors as well as to understand the basic F. hepatica epidemiology in relation to temporal and regional changes in climate and landscape in Cuba is needed.

\section{Methods}

\section{Study area}

The study was conducted in Camagüey province, eastern Cuba. Camagüey has a surface of $15,615 \mathrm{~km}^{2}$ and a tropical climate with an average annual temperature and rainfall of $24.7^{\circ} \mathrm{C}$ and $1200 \mathrm{~mm}$ (www.one.cu), respectively. Elevation varies slightly, from sea level at the coast to $100 \mathrm{~m}$ in the center. According to the milk industry department of the Ministry of Agriculture, in Camagüey, approximately 10,000 dairy farms provide milk to a dairy cooperative during the rainy season (March-July); however, during the dry season (August-February) the number of dairy farms providing milk dropped to below 6000 (Reynaldo González, personal communication). 
Table 4 Multivariable linear regression model of management factors associated with $F$. hepatica ODR measured in bulk-tank milk samples in Camagüey province, Cuba ${ }^{a}$

\begin{tabular}{llll}
\hline Parameter & B & Std. Error & Sig. \\
\hline Intercept & 0.579 & 0.025 & $<0.001$ \\
Grass proportion dry season (\%) & & & 0.004 \\
$81-100$ & -0.110 & 0.033 & 0.001 \\
$50-80$ & -0.022 & 0.022 & 0.317 \\
$<50$ & Base & & \\
Municipality & & & $<0.001$ \\
Camagüey & 0.070 & 0.033 & 0.033 \\
Céspedes & 0.060 & 0.054 & 0.268 \\
Esmeralda & -0.062 & 0.048 & 0.197 \\
Florida & -0.010 & 0.044 & 0.827 \\
Guaimaro & -0.099 & 0.035 & 0.005 \\
Jimaguayú & 0.009 & 0.033 & 0.791 \\
Minas & -0.046 & 0.046 & 0.308 \\
Najasa & -0.112 & 0.036 & 0.002 \\
Nuevitas & 0.040 & 0.046 & 0.374 \\
S.Cubitas & -0.198 & 0.042 & 0.000 \\
Santa Cruz del Sur & 0.006 & 0.036 & 0.874 \\
Sibanicú & -0.093 & 0.038 & 0.015 \\
Vertientes & Base &. &. \\
\hline a $R^{2} 0.204, N=516$ dary & & &
\end{tabular}

${ }^{\mathrm{a}}\left(R^{2}=0.204, N=516\right.$ dairy herds $)$

\section{Sampling and laboratory procedure}

The farms were selected based on the following criteria: (a) storage of farm production data in the milk industry department of the Ministry of Agriculture, in Camagüey; (b) providing milk during the whole year; (c) proportionally according to the total farm per municipality and (d) farmers agree to participate. Using the RANDBETWEEN function in Microsoft $^{\ominus}$ Excel, 650 BTM samples were randomly chosen out of all available regional samples $(\mathrm{N} \approx 6000)$. We collected the samples during the period of May-July 2014. The 650 dairy farms were located across the 13 municipalities in Camagüey. We transported the samples to the laboratory within $4 \mathrm{~h}$ after collection. The samples were kept at $4{ }^{\circ} \mathrm{C}$ between collections on the farms. After arrival at the laboratory, the milk samples were centrifuged $(16,000 \times$ $g$, $5 \mathrm{~min}$ ), fat was skimmed off and the supernatant was collected and frozen at $-20{ }^{\circ} \mathrm{C}$ (for a maximum period of three months) until further analysis.

Samples were analyzed using a commercially available ELISA test (SVANOVIR ${ }^{\circledR} F$. hepatica-Ab, Svanova Biotech, Uppsala) according the manufacturer's instructions. The ELISA results are expressed as optical density ratios $(\mathrm{ODR}) . \mathrm{ODR}=(\mathrm{OD}-\mathrm{NC}) /(\mathrm{PC}-\mathrm{NC})$, where OD is the optical density at $405 \mathrm{~nm}$ of the sample and $\mathrm{NC}$ and $\mathrm{PC}$ are the OD at $405 \mathrm{~nm}$ of the negative and positive controls, respectively.

\section{Questionnaire}

We collected the management data by interviewing the farmers in person. Information was collected on location, herd size, type of production (private or state), watering place [pool/pond/brook or well], pasture management and other husbandry practices, and anthelmintic control measures in adult cows. A complete list of the collected variables is provided in Table 1. Milk production data were collected from the milk industry department of the Ministry of Agriculture.

\section{Associations between $F$. hepatica antibody levels and milk yield}

The association between $F$. hepatica BTM antibody level (ODR) and the average milk yield per cow per year (referred to as "milk yield") was first investigated by the Pearson correlation coefficient. Next, milk yield was compared by a one-way ANOVA with a Student-Newman-Keuls multiple comparisons post-hoc test between the quartiles of the F. hepatica ODR. In addition, one-way ANOVA, was also used to evaluate the association of farm management factors with milk yield, for each management factor independently. Finally, a multivariable model was built to assess the association of $F$. hepatica ODR with farm management factors (=independent variables) and milk yield (= outcome variable).

\section{Associations between $F$. hepatica antibody levels and management variables}

First, a one-way ANOVA was used to test for significant differences in ODR between the different categories of each farm management factor. The differences were further analyzed using the Student-Newman-Keuls multiple comparisons post-hoc test. For comparisons of factors with only two categories, the Student t-test was used.

Factors that were significant in this first screening $(\alpha=$ 0.05 ) were evaluated in a multivariable linear regression model that was constructed by forward stepwise selection of variables with a nominal significance level of $\alpha=0.05$ and 0.10 for the entry and removal of a variable, respectively. Two-way interactions between the variables included in the final model were evaluated for significance. In all the above models, a level of $\alpha=0.05$ was used to declare a variable to be statistically significant. The analysis was conducted in SPSS v21.0 (SPSS Inc., Chicago, USA).

\section{Abbreviations}

BTM: Bulk tank milk; CCS: (Cooperativa de Crédito y Servicio) Credit and Service Cooperative; CPA: (Cooperativa de Producción Agropecuaria) Agricultural Production Cooperative; ODR: Optical Density Ratios; UBPC: (Unidades Básicas de Producción Cooperativa) Basic Units of Cooperative Production (The new farms which now make up the largest sector in Cuban agriculture); UEB: (Unidades Empresariales de Base) Stateowned Basic Business Units 


\section{Acknowledgments}

We express our gratitude to the farmers that participated in the survey and the ministry of Agriculture for their support. We thank Dr. John van der Meer (Pan-American Marine Biotechnology Association) for advice on English improvement of the manuscript.

\section{Funding}

This research has been supported by the Belgian Development Cooperation through VLIR-UOS. VLIR-UOS supports partnerships between universities and university colleges in Flanders (Belgium) and the South looking for innovative responses to global and local challenges. Visit www.vliruos.be for more information.

\section{Availability of data and materials}

The datasets used and/or analyzed during the current study are available from the corresponding author on reasonable request.

\section{Authors' contributions}

Conception and study design: AA, JV, JC; Collection of milk samples and milk processing by ELISA: YG, LQ, DV, DS, MP, AS, AD, YS, SC; questionnaire interviews: YG, LQ, DV, DS, MP, AS, AD, YS; Statistical analysis: AA, JC; Drafting the manuscript: $A A, J C$, and JVD; Interpretation of data, revising manuscript critically AA, JV, JC; JvD. All authors read and approved the final manuscript.

\section{Ethics approval and consent to participate}

Prior to the interview, farmers gave their written agreement to participate in the study. Following the recommendations of the Cuban Legislation No 180/ 07 (Gaceta Oficial 084, 19/12/2007), this field study on commercial dairy herds did not require ethical approval. Consent to use farm production data was given by the Cuban Ministry of Agriculture department.

\section{Consent for publication}

Not applicable

\section{Competing interests}

The SVANOVIR ${ }^{\oplus}$. hepatica-Ab ELISA is commercialized by Boehringer Ingelheim Svanova under a license agreement with Ghent University.

\section{Publisher's Note}

Springer Nature remains neutral with regard to jurisdictional claims in published maps and institutional affiliations.

\section{Author details \\ ${ }^{1}$ Department of Morpho-Physiology, University of Camagüey Ignacio Agramonte Loynaz, Km 5 1⁄2, 74650 Camagüey, Cuba. ${ }^{2}$ Department of Virology, Parasitology and Immunology, Faculty of Veterinary Medicine, Ghent University, Salisburylaan 133, 9820 Merelbeke, Belgium. ${ }^{3}$ Centre for Preventive Medicine, Animal Health Trust, Lanwades Park, Kentford, Newmarket, Suffolk CB8 7UU, UK. ${ }^{4}$ Kreavet, Hendrik Mertensstraat 17, 9150, Kruibeke, Belgium.}

Received: 20 March 2018 Accepted: 17 October 2018 Published online: 08 November 2018

\section{References}

1. AHDB. World Milk Production. 2015. (dairy.ahdb.org.uk)

2. Ponce P. Un enfoque crítico de la lechería internacional y cubana. Rev Sal Anim. 2009;31:77-85

3. Milera MC. López O, Alonso O. Principios generados a partir de la evolución del manejo en pastoreo para la producción de leche bovina en Cuba. Pastos y Forrajes. 2014;37:382-91.

4. Howell A, Baylis M, Smith R, Pinchbeck G, Williams D. Epidemiology and impact of Fasciola hepatica exposure in high-yielding dairy herds. Prev Vet Med. 2015;121:41-8.

5. Charlier J, van der Voort M, Kenyon F, Skuce P, Vercruysse J. Chasing helminths and their economic impact on farmed ruminants. Trends Parasitol. 2014;30:361-7.

6. Githiori J, Höglund J, Waller P, Baker R. Evaluation of anthelmintic properties of some plants used as livestock dewormers against Haemonchus contortus infections in sheep. Parasitology. 2004;129:245-53.
7. Mezo M, González-Warleta M, Carro C, Ubeira FM. An ultrasensitive capture ELISA for detection of Fasciola hepatica coproantigens in sheep and cattle using a new monoclonal antibody (MM3). J Parasitol. 2004;90:845-52.

8. Reichel MP, Vanhoff K, Baxter B. Performance characteristics of an enzymelinked immunosorbent assay performed in milk for the detection of liver fluke (Fasciola hepatica) infection in cattle. Vet Parasitol. 2005;129:61-6.

9. Charlier J, De Cat A, Forbes A, Vercruysse J. Measurement of antibodies to gastrointestinal nematodes and liver fluke in meat juice of beef cattle and associations with carcass parameters. Vet Parasitol. 2009;166:235-40.

10. Bennema S, Vercruysse J, Claerebout E, Schnieder T, Strube C, Ducheyne E, et al. The use of bulk-tank milk ELISAs to assess the spatial distribution of Fasciola hepatica, Ostertagia ostertagi and Dictyocaulus viviparus in dairy cattle in Flanders (Belgium). Vet Parasitol. 2009;165:51-7.

11. Charlier J, Duchateau L, Claerebout E, Williams D, Vercruysse J. Associations between anti-Fasciola hepatica antibody levels in bulk-tank milk samples and production parameters in dairy herds. Prev Vet Med. 2007;78:57-66.

12. Bennema SC, Vercruysse J, Morgan E, Stafford K, Höglund J, Demeler J, et al. Epidemiology and risk factors for exposure to gastrointestinal nematodes in dairy herds in northwestern Europe. Vet Parasitol. 2010;173:247-54.

13. Mezo M, González-Warleta M, Castro-Hermida JA, Muiño L, Ubeira FM Association between anti-F. hepatica antibody levels in milk and production losses in dairy cows. Vet Parasitol. 2011;180:237-42.

14. Brito $A E$, Hernández MA, Fe P, Silveira EA. Prevalence, liver confiscation and economic losses by Fasciola hepatica in bovine slaughterhouses of three provinces of the central region of Cuba. Rev Electron Vet. 2010;11:1-7.

15. González R, Pérez Ruano M, Brito S. Fasciolosis bovina. Evaluación de las principales pérdidas provocadas en una empresa ganadera. Rev Sal Anim. 2007;29:167-75

16. Mazeri S, Sargison N, Kelly RF, Barend M, Handel I. Evaluation of the performance of five diagnostic tests for Fasciola hepatica infection in naturally infected cattle using a Bayesian no gold standard approach. PLoS One. 2016;11:e0161621.

17. Charlier J, Hostens M, Jacobs J, Van Ranst B, Duchateau L, Vercruysse J. Integrating fasciolosis control in the dry cow management: the effect of closantel treatment on milk production. PLoS One. 2012;7:e43216.

18. Takeuchi-Storm N, Denwood M, Hansen TVA, Halasa T, Rattenborg E, Boes J, et al. Farm-level risk factors for Fasciola hepatica infection in Danish dairy cattle as evaluated by two diagnostic methods. Parasit Vectors. 2017;10:555.

19. Keyyu J, Kassuku A, Msalilwa L, Monrad J, Kyvsgaard NC. Cross-sectional prevalence of helminth infections in cattle on traditional, small-scale and large-scale dairy farms in Iringa district, Tanzania. Vet Res Comm. 2006;30: 45-55.

20. Yildirim A, Ica A, Duzlu O, Inci A. Prevalence and risk factors associated with Fasciola hepatica in cattle from Kayseri province. Turkey Rev Med Vet (Toulouse). 2007;158:613

21. Brockwell YM, Elliott TP, Anderson GR, Stanton R, Spithill TW, Sangster NC. Confirmation of Fasciola hepatica resistant to triclabendazole in naturally infected Australian beef and dairy cattle. Int J Parasitol Drugs Drug Resist. 2014;4:48-54.

22. Bennema S, Ducheyne E, Vercruysse J, Claerebout E, Hendrickx G, Charlier J. Relative importance of management, meteorological and environmental factors in the spatial distribution of Fasciola hepatica in dairy cattle in a temperate climate zone. Int J Parasitol. 2011;41:225-33.

23. McCann CM, Baylis M, Williams DJL. The development of linear regression models using environmental variables to explain the spatial distribution of Fasciola hepatica infection in dairy herds in England and Wales. Int J Parasitol. 2010;40:1021-8.

24. Charlier J, Vercruysse J, Morgan E, Van Dijk J, Williams D. Recent advances in the diagnosis, impact on production and prediction of Fasciola hepatica in cattle. Parasitology. 2014;141:326-35.

25. Knubben-Schweizer G, Torgerson PR. Bovine fasciolosis: control strategies based on the location of Galba truncatula habitats on farms. Vet Parasitol. 2015;208:77-83 